\title{
Broadening research in gender and music practice
}

\author{
ANN WERNER (1), TAMI GADIR and \\ $S A M$ DE BOISE (10
}

Södertörn University, Culture and Education, Alfred Nobels allé 7, 14189 Huddinge, Sweden

E-mail:ann.werner@sh.se

RMIT University, School of Media and Communication, 124 La Trobe Street, Melbourne, VIC 3000, Australia

E-mail: tami.gadir@rmit.edu.au

Örebro University, School of Music, Theatre and Art, 70182 Örebro, Sweden

E-mail: sam.deboise@oru.se

\begin{abstract}
This article builds on research about gender in music practice, concerned with skewed musical canons, ratios and quotas of gender representation, unfair treatment and power dynamics, and the exclusionary enmeshment with music technologies. The aim is to critically discuss what 'gender' is understood to be, how it has been studied and how gendered power has been challenged, in order to suggest new routes for research on gender and music practice. While we count ourselves among the scholars working in the field and critically investigate our own work as well as that of others, the article addresses some additional concerns to those of previous studies by examining how gender is ontologically constructed in these studies, how intersectional approaches can enrich analyses of gender in music practice and how the material dimensions of music practice can be actively addressed. The conclusions outline suggestions for broadening research in gender and music practice.
\end{abstract}

This article is an appraisal of some of the questions and research topics that scholarship on both gender and music practice has dealt with, ${ }^{1}$ asking where research on 'women', gender and music has been leading us, in both scholarly and political terms. ${ }^{2}$ In doing so, we review the main strands of previous, predominantly, but not exclusively, Anglophone work on gender and music practice, while discussing theoretical and political approaches to gender. Our literature review is followed by three sections addressing dilemmas facing that research: ontologically binary modes of gender; intersectionality and difference; and the material aspects of music practice. These issues are discussed through our own research on popular music, especially rock, pop and electronic dance music. We engage in conversation with existing music research in our own individual work, namely research in gender

1 A first version of the article was presented collectively at Music and Gender in Balance, a conference in Norway in 2018. For us, the concept of 'balance' in both scholarly discussions and everyday discourses on gender is worth questioning from an epistemological perspective.

${ }^{2}$ We have opted to express gender in this article as artists or people who identify as a given gender. The exceptions to this are when we summarise research that uses different terminologies, in order to remain faithful to the choices researchers have made in their discussions of gender. 
and music practice from mainly the Anglophone world, the Global North and 'the West'. Our aim is to critically discuss how 'gender' is understood and how it is studied in previous research that has been central for this field in order to suggest new routes for research on gender and music practice.

Contemporary studies in music practice from the fields we draw on, including musicology, music history, ethnomusicology, sociology of music, popular music studies and music education, have always sought to address issues of inequality and power around the world. ${ }^{3}$ Whether in terms of lyrics, artist statements or \#MeToo activism, music culture itself is formed within uneven differentials of power. Logically, the ways in which scholars have addressed issues of gender in music practice in particular reflect broader trends within process-oriented ontologies, where gender is constructed in practice rather than pre-existing, in the humanities and social sciences. Early contributions to such discussions are Stern's (1978) work on finding and cataloguing women-identifying composers in classical music, McRobbie and Garber's (1977/1991) feminist challenge to the emphasis on men in subcultural studies of music and Koskoff's (1987) collection of writings on women and their musical activity in different parts of the world. The pool of scholars willing to address questions about what part gender plays in music practice increased in the 1990s, with topics expanding to the complicity of music and musicians in gendered power dynamics. Examples include how gender informs the practices of rock bands and gendered performance and composition in classical music (cf. Bayton 1998; Cusick 2008; McClary 1991).

Today there is a large and growing body of academic research about gender and music, as well as signs of increased interest in gender policy within the global music industries (Raine and Strong 2019). At the same time, there are continuing inequalities in music scenes, reception, histories and the process of music creation. Furthermore, gender studies and feminist theory have continued to develop their theoretical understandings of gender in ways that clearly have implications for studies of gender and music practice. Harding (1986) has argued that feminist theory tends to employ three different epistemologies in the way that knowledge about gender is formed: empiricism, standpoint theory and post-structural feminist theory. Within empiricist feminist knowledge, the focus has been on adding women and their experience to science, arguing that androcentrism has excluded women's experience. Discussing the limits of this approach, Scott (1992) argues that adding women's experience to the canon without challenging the very idea of a canon neither addresses power in a systematic way nor challenges positivist knowledge claims. A standpoint feminist approach, on the other hand, argues that developing knowledge from the point of view of marginal groups should be a main objective given that knowledge itself is always partial. Through their standpoint, women-identifying subjects and others can challenge power structures. While feminist standpoint theory has substantively contributed to theories of science, it fails to fully account for the relationship between woman (subject), femininity and gender. While feminist standpoint theory is largely social-constructivist, post-structural feminist theory aims to challenge the idea of the subject (Butler 1992). On the other hand, in post-structuralist feminist work, language, difference and contradiction are placed

${ }^{3}$ While we draw on research from all of these fields, our focus is on musicology, music education and popular music studies: our own research fields. 
at the centre of attention, which risks decentralising the political work of collectively striving for political change and improving equality in music.

Rather than focusing on whether music is pre-social (cf. Tomlinson 2015) or social (cf. DeNora 2000; Martin 2006), we take as a starting point that music is culturally, historically and geographically contingent and shaped through performance (Small 1998). ${ }^{4}$ Given that in our day-to-day research we directly engage with participants in music settings, we simultaneously treat music as a flexible intellectual concept, while acknowledging music participants' shared understandings of music in its everyday uses within specific spaces.

The remainder of this article is structured as follows: we start with a review of the main strands of research concerned with gender and music practice focusing on their epistemology and continue with thematic sections. The first theme discusses gender ontology and problematises some of the ways that scholars have framed 'gender' and outlined political solutions to power imbalance in research on gender and music practice. The second theme addresses how the idea of music as transformation is troubled by difference and power through intersectional gender theory. The third discusses material conditions and ontological ways of understanding such conditions, affecting who can participate in music practice and how.

\section{Canons and role models}

One of the clearest ways that a gender perspective is present in research on music practice is in the discussion about representation and visibility of women and men in music histories. As Citron (1993) notes, canonisation impacts on the representation of musical histories in that it ascribes value to certain performers and composers. Canon also has performative function - the music of composers in the canon will be played and taught more often. Scholars have observed the discursive gendering of 'musical genius' as masculine in classical music and have challenged the cultural consecration of men in popular music genres such as rock, which has obscured the contributions of women composers and musicians (Battersby 1989; Schmutz and Faupel 2010). Together with other feminist research in the humanities, such examples are among the concerted attempts to change the epistemological foundations of music histories as well as who is included in such histories. Scholars have attempted to 'recover' or more accurately depict the presence of musicians, composers and artists who were not men across genres and activities (Clay 2008; Hinkle-Turner 2003; Pendle and Boyd 2013; Reddington 2007; Rustin and Tucker 2008).

Understanding how musical canons are shaped involves investigating gendered participation in current music cultures. Here, research has found that inequalities structure the types of opportunities and resources allocated to musicians according to gender (Bayton 1998; Donze 2017; Macarthur 2014; Miller 2016). Research about gender and music practice has responded by addressing the quantitative distribution of people in professional music positions. A recent study from the US, for example, shows that only $20 \%$ of most popular hit songs in the US are performed by women-identifying artists and only $10 \%$ of songwriters and less than $2 \%$

${ }^{4}$ In line with the performance turn in music studies (cf. Small 1998) we understand music as an action rather than an object. We also limit the scope of this article by discussing music practice research where participation is in focus. 
of producers are identified as women (Smith et al. 2018, pp. 3-4). Studies of quantitative music participation in US popular music are significant as the country produces a large number of internationally successful artists. Still, 'women' comprise between 10 and $20 \%$ of members within professional organisations in music in Brazil (União Brasileira de Compositores 2016), Sweden (Svenska Tonsättares Internationella Byrå 2016) and the UK (PRS Foundation 2016), indicating that participation imbalance reaches different countries. Furthermore, classical music has also been studied in terms of numerical gender representation and the number of women composers booked among the main concert houses in different countries is low (Kvinnlig Anhopning av Svenska Tonsättare 2016; Macarthur 2014; Women in Music 2016). This also extends to gender imbalances in booking policies across popular music festivals. For example, in Sweden, 'majority-women' acts comprised only $29 \%$ of all festival acts (Jämställd Festival 2017). Across Europe, only $15 \%$ of all DJs who were booked for electronic dance music festivals identified as women (female:pressure 2017). The low numbers of women-identifying composers and artists occur across genres and national contexts. While these studies do not represent the whole world, they show clear trends of imbalance in gender representation and illustrate one prevalent focus in research on gender and music practice: to 'count' the gender of practitioners.

Feminist researchers within gender and music studies have discussed correctives to the aforementioned issues with regard to gender representation. One strategy has been to inspire change through established musicians acting as 'role models' (Bayton 1997, p. 45; Clawson 1999). According to this line of thinking, the elevation of women-identified artists to positions of power and influence encourages others to subconsciously and affectively associate certain activities with themselves through gendered identification with those who are like them. Feminist fan studies on audiences of women/girls relating to artists and gender identity have also examined the importance of role models from which to mould identity. For instance, McRobbie and Garber (1977/1991) have noted how subcultural studies have typically promoted culture for men, by men, on men, and subsequently feminist subcultural studies have served as both an empirical and theoretical corrective to this tendency.

There is a tension between how musical value is understood discursively as gendered - for example, as constructed ideas in musical history and canons (Battersby 1989) - and practical strategies to challenge gender representation, and to promote artists who identify as women as role models. The strength of the latter approach is that it is straightforward in critique of power, and the solutions proposed are easy to understand. Yet when imagining the ways that role modelling is proposed as a means to inspire more young women to participate in musical life, gender is conceptualised in terms of the common-sense idea that 'women' can inspire each other based on a homogeneous understanding of 'womanhood'. This, then, is broadly in line with psychoanalytic models of same-sex identification as a prerequisite to 'normal' gendered identity development. As Butler (2008) has argued, such psychoanalytic models provide partial and inadequate understandings of gender. Furthermore, while approaching the canonisation of music through a feminist critique may aim to deconstruct the norm of the man-identifying composer/musician, there is a risk that the aesthetic criteria by which masculine ideals have been canonised remain uncontested (cf. Macarthur 2014; McClary 1991). As Rustin and Tucker (2008, pp. 11-13) have noted, such an approach risks adding some women to the canon while doing little to change the criteria of the canons themselves. In so doing, such a feminist 
critique of canons has little impact, not disturbing the order or even challenging the idea of what a 'woman' is. Thus, reforming historical canons, critiquing the numbers of women participating in music and seeking ideals about women and music through group identification and role models all imply that political change is something performed on an individual level rather than challenging the notion of what musical quality is. We encourage a critique of the power relations that define what music deserves to be included in canons before focusing on efforts to include more women-identifying artists within such canons.

\section{Discrimination in music practice}

In addition to questions about representation, scholarship on gender and music practice has addressed experiences of discrimination owing to the ways that people exercise power within music practices. For example, music promoters' and organisers' booking policies may appear neutral, but are often realised through, and reinforce, social networks produced through gender, class and race inequalities. To take one example, scholars have demonstrated gender biases in orchestra selection procedures (cf. Goldin and Rouse 2000) and an overreliance on homosocial networks within musical economies (Cameron 2015). Organisers book acquaintances more often than they do strangers, and acquaintances are likely to share identifications with the organiser. Participants in music cultures, especially in gatekeeping roles of record labels or concert venues, are dominated by those identifying as male. This makes access to music spaces skewed.

Gendered forms of socialisation have also been found to privilege certain modes of behaviour that influence participation in music spaces. For instance, as Björck (2013) notes, there are specifically gendered ways of claiming and taking up space, which are instilled in young people from an early age, and which are strengthened by discourses about who has the right to 'claim' space. The combination of discursive resources and lack of social capital makes it more difficult for participants identifying as women and girls to access music in the first place (Clawson 1999). Comparable processes of socialisation and attitudes to taking up space also occur in music education (Green 1997).

At its most overt and violent, exclusion from music also takes the form of sexual harassment and assault. In the wake of the \#MeToo campaign, in Sweden, a staggering 2,192 workers in music industries identifying as women publicly signed a petition on sexual harassment and discrimination (Grönberg 2017). Similar calls in both Australia and Norway highlight sexual harassment and assault in the music industries as a transnational problem (Aftenposten 2017; The Industry Observer 2017). While the sample of countries here mirrors the authors' research contexts, similar discussions all over the world suggest that sexual harassment and assault in the music industries is an international problem. This supports what academic work has regularly demonstrated: that behaviours in music practice range from the undermining of women-identified artists' technical competence in music to misogynistic abuse and sexual assault (Bayton 1997; Farrugia 2012; Gavanas and Reitsamer 2013). Importantly, perceptions of sexual harassment and effects of gender discrimination within music industries differ substantially between men and women in such research.

Feminist studies of music have found that fans commonly experience sexual harassment and additional behaviours and attitudes that devalue them. In 
'masculine'-coded genres such as heavy metal, women- and girl-identifying fans have been considered groupies, and therefore either willing sexual subjects or/and unknowledgeable, superficial enthusiasts (Hill 2016). While music fandom has been understood in a positive light as well (Baym 2007), the fans of genres considered to be of 'low' value, or fans who are themselves considered to be of 'low' value, such as girl-identifying 'tweens', can be subject to delegitimisation in the media. It is easy to see that those who are already marginalised in other areas of social life are ascribed little power and value in their appreciation of music. This is exemplified in Thornton's research on club cultures, in which she finds that knowledge in the form of subcultural capital may be used as a means of excluding 'women' and working-class people from being taken seriously in subcultures as participants or fans (Thornton 1995).

Studies examining how contemporary media depict women-identifying musicians have also demonstrated that discourses circulate differently about musicians across numerous genres, depending on perceptions of gender (Faupel and Schmutz 2011; Hill 2016; Leonard 2007). In line with general ideas about binary and heterosexual gender ideals, the media portray women-identifying musicians as pretty rather than tough, lucky rather than talented, happy rather than serious. There has, however, been a change in portrayals of successful women in music in the 21st century. Many high-profile women-identifying and non-binary musicians are portrayed in various media as capable, strong and even feminist (Krüger Bridge 2020). Yet such ideals frame success as an individual achievement for desirable subjects, mirroring neoliberal values of resilience and individual excellence. In this process, feminine stereotypes are continually deployed and reinforced in relation to a variety of feminised bodies and, as such, continue to be marketable commodities within a late-capitalist system (cf. Gill 2007; James 2015).

In music criticism, aesthetic judgements about the value of so-called 'feminine' music styles (not necessarily performed by women-identifying artists) relate to discourses around music's transcendental qualities, which in turn reinforce gendered narratives about performers and music through the disappearance of (feminine) bodies (Kruse 2002). Claims about musical quality generally are key to the way that cultural intermediaries justify their continued practices of informal discrimination against marginalised groups. As Puwar (2004) highlights in her study of British contexts, drawing on Bourdieusian concepts of field and habitus, such thinking is endemic to institutional cultures. Puwar (2004, p. 131) refers particularly to such narrow perspectives as 'ontological denial' - where those who benefit from the tacit standards of so-called objective cultural value are unable to see the ways that such standards are not natural. In a similar way, discussions about the conditions of participants identifying as women in music practice mark them as other, even when the objective is to pursue equality. This diverts attention from a focus on exclusionary structures and discourses to a politics of rights for those treated 'badly' within which the structures remain unchallenged (cf. Ahmed 2017).

\section{Instruments, technology and genres}

Research has focused on how ideas about gender shape engagement with music instruments, technologies and genre. Binary gender divisions in musical instrument choices, in music education, have continued over a long period (Abeles 2009). Such 
divisions tend to rest on assumptions that activities are either 'masculine' or 'feminine' as well as on the question of whether they 'fit' with the gender of the musician. At the same time, gendered norms associated with some musical instrument have changed throughout history. For example, some data indicate that fewer girls and women take up the electric guitar, the drums, trumpet or trombone, whereas fewer men and boys take up the flute, violin or singing (Wych 2012). At the same time a recent study by Fender from 2018 has shown a growing interest in the guitar by girls, indicating a possible change. ${ }^{5}$ What such studies have in common is the pairing of gender identity with instrument choice in a causal argument. The link between the voice and traditional ideas of femininity has been critiqued for its perceived attribute as a 'natural talent' attached to a physical body, as opposed to other instruments, which are regarded as requiring skill and training to 'master' (cf. Hall 2018). Conversely, analogue and digital music and sound technologies are often regarded as 'masculine' areas and, according to some research, are currently among the most quantitatively, binary-gender-divided activities in contexts of formal training (Born and Devine 2015; de Boise 2018). Born and Devine (2015) discuss how masculinity in music technology is co-constructed by social class in the UK, where music technology programmes in higher education (2007-2012) are dominated by men with lower social class profile than other music programmes. While the authors argue that this may increase class diversity in higher education, they also conclude that gendering of technology is distinctively male. Women's contributions to the development of music technologies have also been found to be erased in discussions of boys' 'inherent' interest (Hinkle-Turner 2003). Such patterns are, according to studies, reinforced by gender dynamics in the interactions between teachers and students, as well as between students, both inside and outside music technology classrooms (Armstrong 2011; Wolfe 2012).

Choosing whether to sing or play the drums can lead to unequal access to careers, and unequal economic opportunities, within and across music scenes. For instance, in societies that place more emphasis on popular music, if more musicians identifying as men are encouraged to play drums or electric guitar, this affords drummers and electric guitarists more opportunities across a wider range of genres than musicians identifying as women singing or playing the flute. The centrality of particular music technologies, especially new digital media, to build and sustain an artistic career is relevant in light of overrepresentation of men-identifying technicians, producers and studio-engineers. Associations between instruments' or activities' difficulty, size and social significance, it has been argued, derive from longstanding gender regimes, which manifest in social judgments surrounding the 'appropriateness' of taking up certain music activities. Research conclude that musicians identifying as women have been actively prohibited from playing instruments that have emphasised their sexuality in both the Global North and South, during different time periods (cf. Essex 1772; Basso 1989; Koskoff 2014; Nannyonga-Tamusuza 2015). In the Western contexts in focus in this article, it is possible to argue that currently informal discouragement rather than active prohibition is more common (cf. Wych 2012).

Music genres have also been analysed by some authors as having been shaped by gendered ideas. For example, Bayton (1998) has argued that rock is masculinised

\footnotetext{
5 https://www.dailyedge.ie/50-per-cent-of-new-guitar-players-are-women-and-its-not-because-of-taylorswift-4291444-Oct2018/ (2020-08-19)
} 
and ascribed greater value than pop, which is associated with femininity. Subcultural practices surrounding certain genres of music are also gendered. For example, when events happen in public places at late hours, they can be understood as gendered masculine (McRobbie and Garber 1977/1991). Music genres become gendered historically and geographically, but the way in which they are gendered also changes over time. Thus, the association of certain genres with femininity prevails, and so too does the devaluing of these genres, in line with notions of masculinity as inherently more valuable. Which genres these are may change over time. In this vein, music scholars, musicians and music fans can be reluctant to deal with issues of status and value within genres themselves. Instead, when faced with questions about social injustices and inequalities in their preferred scenes or genres, they prefer to address broader gender constellations. For example, feminist scholarship on dance music cultures argues that certain club contexts, particularly those centred on specific genres and considered to be 'subcultural', are both safer and provide more space for gender nonconformity for women-identifying clubbers than so-called 'mainstream' contexts (for example, Hutton 2006, pp. 8-10; Pini 2001, pp. 13-14).

\section{Ontologies of gender}

We turn now to a discussion on what is meant by 'gender' in studies of gender and music practice described above. What is clear is that when ontological questions are asked about what gender is in the body of work addressed here, it can tend toward a social-constructivist perspective on gender as performance, bound up with power, and as an identity separate from the 'biological' body. While some studies seem to take for granted the category 'woman', most conceptualise gender as performative. Performance here is often but not always understood in the terms of Butler (2008) as the defining essence of a non-essential gender, or broadly as a social construction or standpoint in structuralist terms (Harding 1986). In this respect, gender is not concerned with men and women, but with constructions or displays of masculinity and femininity, as well as with discursive and institutional structuring and social circulation of such ideas that depends on the discursive articulation of the categories as binary (cf. Leonard 2007). To take one example, Straw (1997, p. 15) discusses record collecting as an activity defined by a masculine popular music culture. To take another, McRobbie (1980/1991, p. 17) suggests that subcultures presume particular constructions of masculinities juxtaposed with opposite constructions of femininities. Both authors distinguish between men and the construction of masculinity as a socially constructed performance.

However, when choosing women-identifying artists or fans to make claims about femininity and vice versa, the line between women and femininity will be invariably blurred, with the risk that one is reduced to the other. As such, 'gender' in music practice research often boils down to empirically interrogating men- and women-identifying participants. This, in turn, risks reinforcing ideas about gender as a binary construction of two mutually exclusive categories with different abilities, even if part of such discussions is that performances are separate from biological bodies. By way of illustration, to argue that there is a need for role models in order for women-identifying participants to enter music, this can unwittingly reinforce the logic of gender as a binary, where the role models themselves are implicitly presumed to be 'women' for 'women'/'girls'. This action limits ideas about what a 
woman is - that is, to a different type of human from a man, not necessarily defined through a relation to femininity and heterosexuality - and who 'women' are - the white, middle class, cis-gendered and able-bodied woman is often used as example. The former risks strengthening the idea that, for instance, a 'real' DJ is a certain kind of man, by equating women-identifying DJs as exceptions that prove the rule. It also strengthens the tendency for one woman-identifying musician to represent all women-identifying musicians or, in contrast, be the token woman on the line-up to prove that women are not excluded.

Setting out to critique stereotypical gendering in music practice thus risks performing precisely such gendering, when critiques involve adding women-identified composers and musicians or analysing how 'women and girls' are marginalised in everyday musical cultures. It is easy to conflate femininity with cis-women, or even to let women act as a stand-in for gender - a concept that is more complex than the divide between biology and socialisation would suggest (Alaimo and Hekman 2008; Coole and Frost 2010). Here we want to use our own work as example of how the problem of binary ontology of gender may take place. One of us has analysed young girls' music consumption in Sweden, addressing how popular music contributes to forming not only gender, but also class and ethnicity (Werner 2009, 2012, 2013). This work defines gender as constructed in cultural interaction with other material and discursive power dimensions in music. These processes were seen as discursive and embodied even though discourse and embodied practice did not always match (participants in the study showed skills in finding and attaining music with media technology while understanding themselves as unskilled in media technology; Werner 2009). Still, the selection of teenage girls as the bearers of gender was central to the design of the study and constituted the empirical examples illustrating identity in gender and music. In such a case, it is possible to confuse femininity with girls and both of these with gender.

While the slippage between girl/woman, femininity and gender is an ontological problem, our concern is for the consequences for research if reinforced too often. In light of this, it is important to stress that the disciplinary nature of language and discourse is a productive insight from poststructuralist feminism that has real material consequences. Research on gender and music focuses too often only on women and girls. This risk is to reproduce the idea of women as a distinctly gendered group that needs to be researched and added to scholarly debate about music. Thus, research in gender and music practice can become too concerned with counting women, analysing women and adding women, rather than focusing on the structures that allow exclusion precisely because they are rendered as 'normal', 'neutral' or 'objective'. This substantially limits the questions we can ask and the knowledge we can gain on gender, power and music. We argue against focusing on participants identifying as women and others as in need of inclusion, where inclusion 'requires being behind the institution' (Ahmed 2017, p. 263). Instead, we suggest that attention must also be paid to such structures themselves as gendered and therefore discursively producing the same notions of lack that feminist research has sought to counter.

\section{An intersectional critique}

In addition to questions over the ontological status of gender, scholars have highlighted that 'woman' has come to stand for white woman, middle-class woman, 
Western woman, heterosexual woman, cis-woman or all of the above. As Crenshaw (1991) and Collins (1998) have argued, when it comes to subjects, structures and political strategies, power dynamics of gender, race and class intersect. Theories of intersectionality have subsequently been adopted in Europe and taken on slightly different meanings, where notions of ethnicity and nation have been more central than 'race' (cf. Lykke 2003). Regardless of such differences, rather than simply 'adding' categories of oppression to each other, intersectionality means recognising the irreducibility of power dimensions to each other (Yuval-Davis 2006). As such, intersectionality suggests that gender can never be seen as the only category through which to analyse power, including as it manifests in the music industries. Political intersectionality, as discussed by Crenshaw (1991), also suggests that political action needs to address multiple dimensions of power. Gender equality cannot be pursued without addressing power dimensions of for example social class, racism and transand homophobia in music practice.

An intersectional critique can be extended to critique the notion that music carries an inherent capacity for positive transformation. Scholars across music studies have discussed music's enriching capacities at the level of individual or group affective states (cf. Hesmondhalgh 2013; Thompson and Biddle 2013), political activism (Shank 2014; Street 2012), senses of belonging and identity through consumption (DeNora 2000; Malbon 1999), and dissolving race, gender, and class (Fikentscher 2000; Pini 2001). The elevation of music's agency to transform inequalities is prevalent across scholarship ranging from the 'harder' music sciences to cultural theory and philosophy, as well as in popular writing and media. Here, DJ-based dance music culture for a Western audience is used as an example of a commonly cited case for individual or collective (subversive) transformation (also critiqued: Saldanha 2007). It is likely due to dance music's overtly corporeal form, as well as its cultural-historical legacy of societal marginality, that the genre is often seen in this way (cf. Lawrence 2016, 2003). Scholars draw parallels between sounds, spaces and intoxicant-related experiences to individual escapism in phenomenologies of pleasure (cf. Garcia 2015; Rietveld 2018), political resistance or activism through dance and spiritual awakening. The idea is that music's transformative potential is available to all. Yet many dance music participants who define their musical cultures as transformative enact intersecting class, race and gender prejudices, highlighting that music's transformative potential is not universal but affected by intersecting power asymmetries (Gadir 2016, p. 4, 2018, para. 3.2; Thornton 1995, pp. 87, 99-101, 109). Furthermore, while some participants (for example, women identifying, trans- and non-binary people) attempt to access transformative experiences, others actively prevent them from doing so (cf. Gadir 2016, 2017). Intersectional gender research also needs to highlight how racialisation materialises in dance culture settings. For example, while some white bodies are dancing, brown bodies are serving drinks and cleaning (cf. Saldanha 2007).

To emphasise music as transformative in research is to underemphasise the aforementioned lack of access, on or off the dance floor itself. One common way is through the surveillance of potential entrants to dance floor spaces at night club doors. Decisions that determine a potential party-goer's acceptance or refusal to an event can be based on stereotypes about how particular bodies do or do not constitute a 'good fit' to the 'vibe' of a dance floor. To draw again on Puwar (2004), such cases emphasise which publics and performers are deemed to be natural 'fits' to 
which venues and illustrate how a 'natural fit' is shaped by intersections of different power dimensions. Questioning by door security tends to imply rather than expressly articulate class, racial or gender prejudices, such as appropriateness of someone's outfit or shoes, whether they can answer which DJs are playing on a given night, or how they behave with their friends before approaching door security. Door security staff may turn away groups of women who appear to be on a hen night, dressed in recognisably white working-class feminine styles in the UK, from events focused on genres dominated by male fans. The basis for refusing entry is thus to be found at the intersection of gender, race and class, where their attire is labelled as 'too trashy' and where those on the door deem them too intoxicated. Levels of acceptable intoxication tend to be judged differently for different gendered, raced and classed groups (cf. Hutton 2006; Pini 2001).

However, doing intersectional analysis of power in music practice is multilayered. Managerial staff at night clubs, such as Berlin's Berghain, claim that practices of selectivity at the point of entry actually safeguard spaces designed specifically for queer marginalised groups who are often not safe on other dance floors. Such a perspective is voiced to reflect the histories of specific dance spaces such as venues in New York City in the 1970s and 1980s, aimed at queer people of colour (Fikentscher 2000; Lawrence 2003, 2016). ${ }^{6}$ In Oslo, Norway, and Edinburgh, UK, which have been the primary sites of one of the authors' research, genre-based electronic dance music communities such as those centred on techno, house, or drum ' $n$ ' bass are frequented by a majority of white, middle-class, cis-men. Demographics make this intersection of gender, race and class invisible through their dominance, and normalise prejudice and discrimination, while furthering the idea of music as having universal potential for transformation.

Furthermore, participants of certain 'underground' scenes (across genres) often tend to view their scenes as already anti-establishment, with the idea that the act of participation itself is political and transformative. In other words, fans of music with 'non-mainstream' aesthetics often view their participation in such communities as inherently activist or oppositional without questioning power trajectories within the scene. It is evident in conversations between members of close-knit music communities that many participants presume, often justifiably, that they share a common worldview, including on politics and social issues. Insiders might not 'see' gender, race and class intersecting in their culture as power dynamics because the politics that they are concerned with lie in 'the music itself' and in the 'talent' of those who play it (Gadir 2017, pp. 61-4). An intersectional methodological approach to music practices should be used to complicate such research areas, and further problematise assumptions about the focus for studies of gender and music practice.

\section{Material concerns}

Finally, while much previous research in gender and music practice has focused on what musicians and music-makers do, the questions of the actual material conditions of music-making where humans meet other agents and structures have been less in

\footnotetext{
6 Safeguarding queer-spaces are further complicated when used to justify homonationalism (Puar 2007) whereby 'immigrant', Muslim and Middle Eastern others are seen as a threat to queer individuals, who are seen as nationals.
} 
focus (cf. Leonard 2007). Importantly, material questions of how to fund and support musicians, as well as spaces, organisations and activities are influenced by national, transnational policies and legislation (cf. Larsson and Svenson 2001; Strong et al. 2018). For instance as one of the article's authors has shown, a more sustained policy focus on 'mainstreaming gender' in Sweden has arguably meant that women are more represented in music education institutions in Sweden compared with the UK (de Boise 2018). Thus, the material effects of different cultural policy traditions, rather than the musicians themselves, should be more carefully interrogated.

Importantly, music-making does not just happen without some kind of financial and material support. 'Canonical' composers have historically relied on benefactors to support their development (DeNora 2017) and music practitioners of all kinds continue to need money to live and play. The supplementary labour that musicians undertake and their responsibilities outside of music are embedded in gender: domestic and waged labour are both highly gendered (Fraser 2013). Crucially, analysing political economies of music implicates social and discursive power dimensions, which are implicitly intertwined with assumptions about what types of music 'deserve' support from governmental and non-governmental funders. This is particularly visible at the state level - governments in northern/Western Europe financially prioritise music where ethnic majority populations and middle-classes are heavily represented - such as classical music (cf. Scharff 2015, p. 13). Even among the groups most active in fighting against gender inequalities, those deemed to promote 'respectable' femininity (Tate 2012) or even 'respectable' feminisms (Scharff 2011) are more likely to be financed. Respectability itself is already firmly classed and raced. As such, feminist groups in music practice that promote so-called respectable women (white, cis, straight and middle-class) or are perceived to be respectable in their aims (promoting women-identifying classical composers) are more likely to be viewed favourably by organisations who grant funding or licences to host events. This focus also involves looking not only at who is invited to play, but also whether they are paid equally and given similar material conditions.

Cohen's (1991) pioneering work on rock culture in Liverpool is among the studies that have paid attention to the material aspects of music practice and gender. Cohen has demonstrated how perceptions that particular venues and rehearsal spaces were in 'dangerous areas' of the city intersected with discourses surrounding girls and women's responsibility to ensure their own physical safety. At the same time, the notion of 'danger' and what constitutes a 'threat' are inextricable from class and race. In the UK, research has studied how the Metropolitan police have shut down or denied permission to organisers of 'grime' nights, closely linked to Black British communities, by claiming they are dangerous (Charles 2016). The notion of so-called 'dangerous spaces', as discussed in Ahmed (2017) and Puwar (2004), thus plays a significant role in informing cultural policy and discourse about which music is seen to 'deserve' state or financial support more broadly. This means that such state policies accentuate and heighten the material disadvantages endured especially by women of colour who may already be both representationally and discursively marginalised in such scenes and who are disadvantaged in a variety of ways by racist and misogynistic policies.

New-materialist feminist approaches look to theorise the interplay between the material and the discursive in ways that can be productive for scholars working on music and gender. In such thinking, ideas, economics, bodies, environments and technologies are seen as co-constitutive and the idea of the subject is not privileged 
as the site of focus (Alaimo and Hekman 2008; Coole and Frost 2010). Instead of seeing the subject and music practice as the primary area of study situated in a material condition, this involves understanding the subject as made up of events of music, money, an instrument or a pair of headphones, as well as discourses and affects.

\section{Conclusion}

As detailed above, there is a significant breadth of existing research in gender and music practice. In this article, we have considered the objects and methods of study that research in gender and music practice defaults to, acknowledging our own tendencies to fall back into such categorisations. What we articulate is what we see as three key problems in research on gender and music practice. The first involves an assumption of a gender binary that counts and adds women-identifying composers, musicians and fans, with the implication that gender is concerned with cis-women and their individual empowerment. Such research can, even without intending to, shift the focus from power structures to individuals. Second, research that fails to address the intersectionality of gender with other power dimensions fails to understand the larger ways that power works in music practice. Third, research in gender and music practice focuses on humans and discourse while tending to sidestep material processes and objects that are also central to power's interplay with music practice.

Throughout the article we have made some suggestions of possible routes to take to avoid these three problems. This article challenges the focus on measuring gender balance, introducing role models and adding women-identifying musicians and others to canons and line-ups by shifting the focus from 'women in music' to (intersectionally constructed) structures and cultures in music practice. Such a shift of focus could include considerations of definitions of quality in any canon or genre, or explore practical ways in which musicians work beyond canons themselves. It could also include the institutions of musical practice and how power is organised within them. Another suggestion is to pay greater attention in academic research and debate to the interplay of multiple power dimensions, in discourse and material conditions, while researching gender in music practice. Focusing on gender alone cannot challenge locally specific and ambiguous practices of power.

Following the discussions in this article, we argue that the object of research what gender is and does - should continue to be expanded in studies of gender and music practice. While we have challenged research counting women in music practice, we acknowledge that such quantitative studies may well be needed to motivate the music industries to strive for change. But they are not enough by themselves. We suggest that areas of conflict and contestation are also introduced in addressing differences within the group defining themselves as women, non-binary or trans, which might include class, race, sexuality or dis/ability. It also raises questions about ontology and the role of the subject, for example, is there a unified subject? If not, what elements or entities can be regarded as part of the subject and what aspects in particular should music researchers be focused on? There might be a productive way of thinking about a feminist musical subjectivity that recognises such heterogeneity. Instead of shying away from such conflicts, we believe that it is valuable to actively discuss and confront the complicated nature of gender ontology and power in order to continue to develop gender and music practice as a vital field of research. 


\section{References}

Abeles, I. 2009. 'Are musical instrument gender associations changing?', Journal of Research in Music Education, 57/2, pp. 127-39

Aftenposten. 2017. '\#nårmusikkenstilner: "Plutselig stakk han to fingre inn i meg under skjørtet mitt": 1110 kvinner snakker i dette oppropet ut mot overgrep i norsk musikkbransje', Aftenposten. https://www.aftenposten.no/ kultur/i/qnp89z/narmusikkenstilner-Plutselig-stakk-han-to-fingre-inn-i-meg-under-skjortet-mitt (accessed 23 December 2017)

Ahmed, S. 2017. Living a Feminist Life (Durham, NC, Duke University Press)

Alaimo, S., and Hekman, S. (eds) 2008. Material Feminisms (Bloomington, IN, Indiana University Press)

Armstrong, V. 2011. Technology and the Gendering of Music Education (Aldershot, Ashgate)

Basso, E. 1989. 'Musical expression and gender identity in the myth and ritual of the Kalapalo of central Brazil', in Women and Music in Cross Cultural Perspective, ed. E. Koskoff (Champaign, IL, University of Illinois Press), pp. 163-76

Battersby, C. 1989. Gender and Genius: Towards a Feminist Aesthetics (London, The Women's Press)

Baym, N.K. 2007. 'The new shape of online community: the example of Swedish independent music fandom', First Monday, 12(8). https://firstmonday.org/ojs/index.php/fm/article/download/1978/1853

Bayton, M. 1997. 'Women and the electric guitar', in Sexing the Groove: Popular Music and Gender, ed. S. Whitely (London, Routledge), pp. 37-49

Bayton, M. 1998. Frock Rock: Women Performing Popular Music (Milton Keynes, Open University Press)

Björck, C. 2013. 'A music room of one's own: discursive constructions of girls-only spaces for learning popular music', Girlhood Studies, 6/2, pp. 11-29

Born, G., and Devine, K. 2015. 'Music technology, gender, and class: digitization, educational and social change in Britain', Twentieth-Century Music, 12 /2, pp. 135-72

Butler, J. 1992. 'Contingent foundations: feminism and the question of "postmodernism"', in Feminists Theorize the Political, ed. J. Butler and J.W. Scott (New York, Routledge), pp. 3-21

Butler, J. 2008. Gender Trouble, 4th ed. (London, Routledge)

Cameron, S. 2015. Music in the Marketplace: A Social Economics Approach (Abingdon, Routledge)

Charles, M. 2016. 'Grime central! Subterranean ground-in grit engulfing manicured mainstream spaces', in Blackness in Britain, ed. K. Andrews and L.A. Palmer (London, Routledge), pp. 89-100

Citron, M. 1993. Gender and the Musical Canon (Champaign, IL, University of Illinois Press)

Clawson, M.A. 1999. 'When women play the bass: instrument specialization and gender interpretation in alternative rock', Music Gender and Society, 13/2, pp. 193-210

Clay, A. 2008. "Like an old soul record": black feminism, queer sexuality, and the hip-hop generation', Meridians, 8/1, pp. 53-73

Cohen, S. 1991. Rock Culture in Liverpool (Oxford, Oxford University Press)

Collins, P.H. 1998. 'It's all in the family: intersections of gender race and nation', Hypatia, 13/3, pp. 62-82

Coole, D. and Frost, S. 2010. New Materialisms: Ontology, Agency and Politics (London, Duke University Press)

Crenshaw, K. 1991. 'Mapping the margins: intersectionality, identity politics and violence against women of color', Stanford Law Review, 43, pp. 1241-299

Cusick, S.G. 2008. "You are in a place that is out of the world ...": music in the detention camps of the "global war on terror"', Journal of the Society for American Music, 2/1, pp. 1-26

de Boise, S. 2018. 'Gender inequalities and higher music education: comparing the UK and Sweden', British Journal of Music Education, 3/1, pp. 23-41

DeNora, T. 2000. Music in Everyday Life (Cambridge, Cambridge University Press)

DeNora, T. 2017. 'Musicians make markets', European Societies, 15/2, pp. 212-28

Donze, P.L. 2017. 'Gender and popular culture: a comparison of promoter and listener preferences for popular music artists', Sociological Perspectives, 60/2, 338-54

Essex, J. 1722. The Young Ladies Conduct: Or, Rules for Education, Under Several Heads; With Instructions Upon Dress, Both Before and After Marriage. And Advice to Young Wives (Cornhill, J. Brotherton)

Farrugia, R. 2012. Beyond the Dance Floor: Female DJs, Technology, and Electronic Dance Music. (Bristol, Intellect)

Faupel, A., and Schmutz, V. 2011. 'From fallen women to madonnas: changing gender stereotypes in popular music critical discourse', Sociologie de l'Art, 18/3, pp. 15-34

female:pressure. 2017. 'Facts 2017 - results', female:pressure. https://femalepressure.wordpress.com/facts/facts2017-results/ (accessed 12 January 2018)

Fikentscher, K. 2000. You Better Work! A Study of Underground Dance Music in New York City (Hanover, NH, Wesleyan University Press)

Fraser, N. 2013. The Fortunes of Feminism: From State Managed Capitalism to Neoliberal Crisis (London, Verso)

Gadir, T. 2016. 'Resistance or reiteration: rethinking gender in DJ cultures', Contemporary Music Review, 35/1, pp. 115-29

Gadir, T. 2017. 'Forty-seven djs, four women: meritocracy, talent and postfeminist politics', Dancecult: Journal of Electronic Dance Music Culture, 9/1, pp. 50-72

Gadir, T. 2018. 'Understanding agency from the decks to the dance floor', Music Theory Online 24/3

Garcia, L-M. 2015. 'Beats, flesh, and grain: sonic tactility and affect in electronic dance music', Sound Studies, $1 / 1$, pp. $59-76$ 
Gavanas, A., and Reitsamer, R. 2013. 'DJ technologies, social networks, and gendered trajectories in European DJ cultures', in DJ Culture in the Mix: Power, Technology, and Social Change in Electronic Dance Music ed. B.A. Attias, A. Gavanas and H. Rietveld (London, Bloomsbury), pp. 51-78

Gill, R. 2007. 'Postfeminist media culture: elements of a sensibility'. European Journal of Cultural Studies, 10/2, pp. $147-66$

Goldin, C., and Rouse, C. 2000. 'Orchestrating impartiality: the impact of "blind" auditions on female musicians.' The American Economic Review, 90(4), pp. 715-41

Green, L. 1997. Music, Gender and Education (Cambridge, University of Cambridge Press)

Grönberg, A. 2017. '\#Närmusikentystnar - Nytt Artistupprop Från Musikvärlden', SVT Nyheter. https://www. svt.se/kultur/musik/nytt-artistupprop-fran-musikvarlden (accessed 23 December 2017)

Hall, C. 2018. Masculinity, Class and Music Education: Boys Performing Middle-class Masculinities through Music (London, Palgrave Macmillan)

Harding, S. 1986. The Science Question in Feminism (Ithaca, NY, Cornell University Press)

Hesmondhalgh, D. 2013. Why Music Matters (Malden, MA, Blackwell)

Hill, R.L. 2016. Gender, Metal and the Media (London, Palgrave Macmillan)

Hinkle-Turner, E. 2003. 'Women and music technology: pioneers, precedents and issues in the United States', Organised Sound, 8/1, pp. 31-47

Hutton, F. 2006. Risky Pleasures? Club Cultures and Feminine Identities (Aldershot, Ashgate)

James, R. 2015. Resilience and Melancholy: Pop Music, Feminism, Neoliberalism (Alresford, Zero Books)

Jämställd Festival. 2017. Jämställd Festival. http://jamstalldfestival.se/ (accessed 10 January 2018)

Koskoff, E. 1987. Women and Music in Cross-cultural Perspective (New York, Greenwood Press)

Koskoff, E. 2014. A Feminist Ethnomusicology: Writings on Music and Gender (Champaign, IL, University of Illinois Press)

Krüger Bridge, S. 2020 (forthcoming). 'Gendering music in popular culture', in The International Encyclopedia of Gender, Media and Communication, ed. K. Ross (New York, Wiley Blackwell)

Kruse, H. 2002. 'Abandoning the absolute: transcendence and gender in popular music discourse', in Pop Music and the Press, ed. S Jones (Philadelphia, PA, Temple University Press), pp. 134-55

Kvinnlig Anhopning av Svenska Tonsättare. 2016. 'Repertoargenomgången 2014/15', Kvinnlig Anhopning av Svenska Tonsättare. http://kvast.org/repertoarstatistik-201415/ (accessed 15 October 2016)

Larsson, T., and Svenson, P. 2001. 'Cultural policy in Sweden', The Journal of Arts Management, Law, and Society, 31/1, pp. 79-96

Lawrence, T. 2003. Love Saves the Day: A History of American Dance Music Culture, 1970- 1979 (Durham, NC, Duke University Press)

Lawrence, T. 2016. Life and Death on the New York Dance Floor, 1980-1983 (Durham, NC, Duke University Press)

Leonard, M. 2007. Gender in the Music Industry: Rock Discourse and Girl Power (Aldershot, Ashgate)

Lykke, N. 2003. 'Intersektionalitet - ett användbart begrepp för genusforskningen', Kvinnovetenskaplig Tidskrift, 2003/1, pp. 47-56

Macarthur, S. 2014. 'The woman composer, new music and neoliberalism', Musicology Australia, 36/1, pp. 36-52

Malbon, B. 1999. Clubbing: Dancing, Ecstasy and Vitality (London, Routledge)

Martin, P.J. 2006. Music and the Sociological Gaze: Art Worlds and Cultural Reproduction (Manchester, Manchester University Press)

McClary, S. 1991. Feminine Endings: Music, Gender, and Sexuality (Minneapolis, MN, University of Minnesota Press)

McRobbie, A. 1980/1991. 'Settling accounts with subcultures: a feminist critique', in Feminism and Youth Culture: From Jackie to Just Seventeen (Basingstoke, Macmillan), pp. 16-34

McRobbie, A., and Garber, J. 1977/1991. 'Girls and subcultures', in Feminism and Youth Culture: From Jackie to Just Seventeen, ed. A. McRobbie (Basingstoke, Macmillan), pp. 1-15

Miller, D.L. 2016. 'Gender and the artist archetype: understanding gender inequality in artistic careers', Sociology Compass, 10/2, pp. 119-31

Nannyonga-Tamusuza, S. 2015. Baakisimba: Gender in the Music and Dance of the Baganda People of Uganda (London, Routledge)

Pendle, K., and Boyd, M. 2013. Women in Music: A Research Information Guide (London, Routledge)

Pini, M. 2001. Club Cultures and Female Subjectivity: The Move from Home to House (New York, Palgrave)

PRS Foundation. 2016. 'Background to women make music', PRS Foundation. http://www.prsformusicfoundation.com/funding/women-make-music-2/background-to-women-make-music (accessed 5 May 2016)

Puar, J.K. 2007. Terrorist Assemblages: Homonationalism in Queer Times (Durham, NC, Duke University Press)

Puwar, N. 2004. Space Invaders: Race, Gender and Bodies Out of Place (Oxford, Berg)

Raine, S. and Strong, C. 2019. Toward Gender Equality in the Music Industry: Education, Practice and Strategies for Change (London, Bloomsbury)

Reddington, H. 2007. The Lost Women of Rock Music: Female Musicians of the Punk Era (Aldershot, Ashgate)

Rietveld, H.C. 2018. 'Machine possession: Dancing to repetitive beats', in Over and Over: Exploring Repetition in Popular Music, ed. O. Julien and C. Levaux (New York, Bloomsbury Academic), pp. 75-88

Rustin, N., and Tucker, S. (eds) 2008. Big Ears: Listening for Gender in Jazz Studies (Durham NC, Duke University Press)

Saldanha, A. 2007. Psychedelic White: Goa Trance and the Viscosity of Race (Minneapolis, University of Minnesota Press) 
Scharff, C. 2011. "'it is a colour thing and a status thing, rather than a gender thing": negotiating difference in talk about feminism', Feminism and Psychology 21(4), pp. 458-76

Scharff, C. 2015. Equality and Diversity in the Classical Music Profession (London, King's College London)

Schmutz, V. and Faupel, A. 2010. 'Gender and cultural consecration in popular music', Social Forces, 89/2, pp. 685-97

Scott, J.W. 1992. 'Experience', in Feminists theorize the political, ed. J. Butler and J.W. Scott (New York, Routledge), pp. 22-41

Shank, B. 2014. The Political Agency of Musical Beauty (Durham, NC, Duke University Press)

Small, C. 1998. Musicking. The Meanings of Performing and Listening (Hanover, NH, University Press of New England)

Smith, S., M. Choueiti, and Pieper, K. 2018. Inclusion in the Recording Studio? Gender and Race/Ethnicity of Artists, Songwriters and Producers across 600 Popular Songs from 2012-2017 (Annenberg Inclusion Initiative, University of Southern California)

Stern, S. 1978. Women Composers: A Handbook (Metuchen, Scarecrow)

Straw, W. 1997. 'Sizing up record collections', in Sexing the Grove: Popular Music and Gender, ed. S. Whiteley (London, Routledge), pp. 3-16

Street, J. 2012. Music and Politics (Cambridge, Polity Press)

Strong, C., Homan, S., O’Hanlon, S. and Tebbutt, J. 2018. 'Uneasy alliances: popular music and cultural policy in the "Music City"', in The Routledge Handbook of Global Cultural Policy, ed. V. Durrer, T. Miller and D. O’Brien (Abingdon, Routledge), pp. 468-81

Svenska Tonsättares Internationella Byrå. 2016. STIM Annual Report 2015 (Svenska Tonsättares Internationella Byrå)

Tate, S. 2012. 'Michelle Obama's arms: race, respectability, and class privilege', Comparative American Studies: An International Journal, 10(2-3), pp. 226-38

The Industry Observer. 2017. '\#Menomore: an open letter to the Australian music industry', The Industry Observer. https://www.theindustryobserver.com.au/me-no-more/ (accessed 3 March 2018)

Thompson, M., and Biddle, I. 2013. 'Introduction: somewhere between the signifying and the sublime', in Sound, Music, Affect: Theorizing Sonic Experience, ed. M. Thompson and I. Biddle (New York, Bloomsbury Academic), pp. 1-24

Tomlinson, G. 2015. A Million Years of Music: The Emergence of Human Modernity (New York, Zone Books)

Thornton, S. 1995. Club Cultures: Music, Media and Subcultural Capital (Cambridge, Polity Press)

União Brasileira de Compositores. 2016. 'UBC Annual Report 2015', União Brasileira de Compositores. http:// www.ubc.org.br/Hotsite/Relatorio_Anual/2015/eng/cap-4.html (accessed 12 July 2017)

Werner, A. 2009. 'Girls consuming music at home: gender and the exchange of music through new media', The European Journal of Cultural Studies, 12/3, pp. 269-84

Werner, A. 2012. 'Emotions in music culture: the circulation of love' Global Media Journal. Australian Edition, 6/1, pp. 1-8

Werner, A. 2013. 'Sexy shapes: girls negotiating gender through popular music', Girlhood Studies, 6/2, pp. 30-46

Wolfe, P. 2012. 'A studio of one's own: music production, technology and gender', Journal on the Art of Record Production, 7.

Women in Music. 2016. 'BBC Proms Survey', Women in Music. http://www.womeninmusic.org.uk/proms-survey.htm (accessed 12 December 2016)

Wych, G. 2012. 'Gender and instrument associations, stereotypes and stratification, a literature review', National Association for Music Education, 30/2, pp. 22-31

Yuval-Davis, N. 2006. 'Intersectionality and feminist politics', European Journal of Women's Studies, 13/3, pp. 193-209 